\title{
Bringing a museum of language to life: the use of multimodal resources for interactional engagement in the Museu da Língua Portuguesa, Brazil
}

Do museu da língua para a vida: o uso de recursos multimodais para engajamento interacional no Museu da Língua Portuguesa, Brasil

Louise Ravelli*

University of New South Wales

Sydney / Austrália

Viviane M. Heberle**

Universidade Federal de Santa Catarina

Florianóplis, Santa Catarina / Brasil

\begin{abstract}
The popular and highly successful Museu da Lingua Portuguesa ${ }^{1}$ in São Paulo, Brazil, is renowned for its visitor engagement strategies. While this success is often attributed to high levels of technological interactivity enabled in the museum displays, we argue that the success of the museum also comes from a range of other multimodal resources. Using a social semiotic approach to spatial discourse analysis, we examine each of the three levels/floors of the museum, identifying the various meaning-making resources across the representational, organizational, and interactional metafunctions. These both differentiate the separate levels of the museum, and bring them together as a unified whole, creating a strong focus on cultural identity and on placing the visitor in the centre of meaning-making practices.
\end{abstract}

KEYWORDS: Museu da Língua Portuguesa; multimodal resources; social semiotic approach; interactive engagement; spatial discourse analysis.

\footnotetext{
*L.Ravelli@unsw.edu.au

** viviane.heberle@ufsc.br

${ }^{1}$ Unfortunately the Museu da Lingua Portuguesa (Portuguese Language Museum) was tragically damaged by fire on December 21, 2015.
} 


\begin{abstract}
RESUMO: O popular e bem-sucedido Museu da Língua Portuguesa na cidade de São Paulo (Brasil) é famoso por suas estratégias de engajamento utilizadas com os seus visitantes. Embora esse sucesso seja frequentemente atribuído ao alto nível de interatividade tecnológica disponível nas exibições do museu, argumentamos que seu sucesso pode também advir de uma série de outros recursos multimodais. A partir de uma abordagem sociossemiótica de análise de discurso espacial, examinamos cada um dos três níveis/andares do museu, identificando os vários recursos de construção de sentido através das metafunções representacional, organizacional e interacional. Esses recursos diferenciam os níveis distintos do museu, mas também os aproximam, criando um foco intenso em relação à identidade cultural e colocando o/a visitante no centro de práticas de construção de sentido.
\end{abstract}

PALAVRAS-CHAVE: Museu da Língua Portuguesa; recursos multimodais; abordagem sociossemiótica; engajamento interativo; análise de discurso espacial.

\title{
1 Introduction
}

Imagine a museum dedicated to the study of language and you will no doubt imagine something rather dull. Perhaps there will be an exhibition with lists of words and dry etymological entries, examples of verb conjugations or even instructions on how to speak 'correctly'. Perhaps it might include recordings in different accents. The highlight could be humorous notes on the misuse of the apostrophe. Even linguists with a passion for language might find it hard to imagine how to make such a museum engaging. But engagement with the public is an essential feature of any contemporary museum, and the Museu da Lingua Portuguesa (MLP), in São Paulo, Brazil, is one of the most popular in South America, having received 2,927,131 visitors since its opening (<2http://www.museudalinguaportuguesa.org.br/ noticias_interna.php?id_noticia $=227>$ ), and has set international standards for public engagement. In this article, we use social semiotic analysis of multimodal texts to explore a number of different strategies used in the museum which facilitate engagement, and argue that these strategies need to be understood as something more than simply enabling 'interaction'. We are thus aligned with researchers in Applied Linguistics who recognize the relevance of new media and the interaction of different semiotic resources in meaning-making (DIAS, 2012; ZACCHI, 2009; HEBERLE, 2012; NASCIMENTO, BEZERRA; HEBERLE, 2011; MOT'TA-ROTH; HEBERLE, 2015). We introduce the museum and the social-semiotic tools used to analyse it, then apply these tools to each of the three levels/floors of the museum, arguing that while each level is strongly differentiated and 
has its own strategies for engagement, the three are also brought together to make a unified whole, resulting in a highly satisfying experience for visitors.

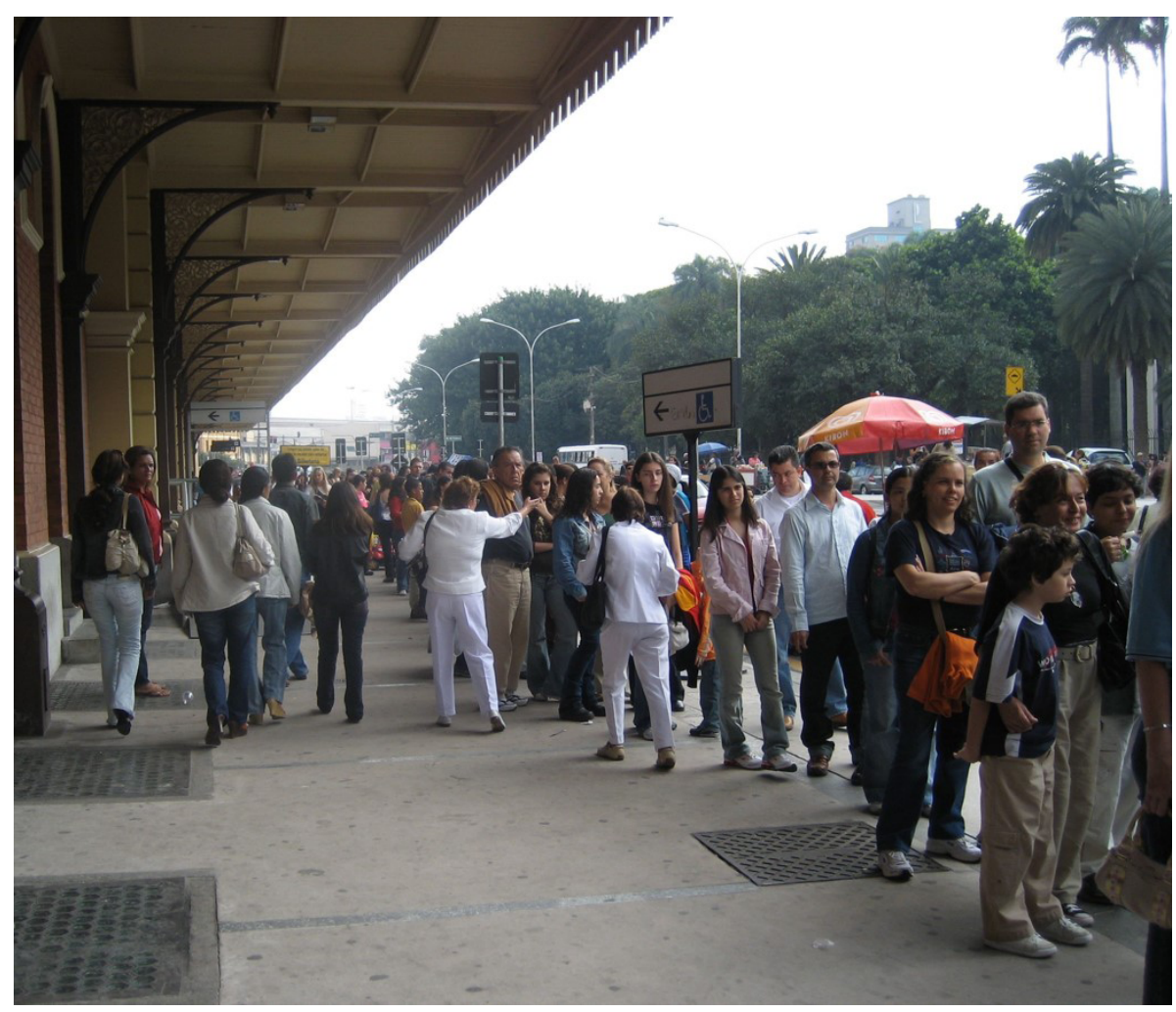

FIGURE 1 - Queues to enter the Museu da Lingua Portuguesa [Photo: author]

\section{The museum}

The $\mathrm{MLP}^{2}$ opened in 2006, on the site of a traditional architectural symbol, Estação da Luz (Luz train station), in São Paulo - the largest Portuguese-speaking city in the world, with a population of around 11

\footnotetext{
${ }^{2}$ For a good overview of the museum as a whole, see the video $<$ https://www. youtube.com/watch?v $=80 \mathrm{mHcbwdUaU}>$, presented by the Director of the Museum, Antônio Carols Sartini (accessed December 2015). Other relevant videos (all accessed December 2015) include: <https://www.youtube.com/watch?v=Z7zMR1TIF6s>; <https://www.youtube.com/watch?v=DwjfnQuE_Mc >; <https://www.youtube.com/ watch?v=afBlYrgpaTA $>$; <http:/ / www.cidadedesaopaulo.com/sp/o-que-visitar/pontosturisticos/207-museu-da-lingua-portuguesa $>$.
} 
million people. The museum's facade maintains the imposing Victorian architecture of its 1901 origins, while the inner portions of the building have been fully reconfigured. Funding for the development of the MLP was granted by the State of São Paulo, the Roberto Marinho Foundation and the Ministry of Culture. Its objectives include the following (<http://www. museudalinguaportuguesa.org.br>; accessed December 8, 2015):

- to show the language as a fundamental and founding element of our culture;

- to celebrate and value the Portuguese language, showing its origins, history and influences;

- to bring citizens closer to their language, showing that it is they who are the real "owners" and agents of change of the Portuguese language;

- to value the diversity of Brazilian Culture;

- to encourage exchange between various Portuguese-speaking countries;

- to promote courses, talks and seminars about the Portuguese language and pertinent themes;

- to hold temporary exhibitions about themes related to the Portuguese language and its diverse areas of influence. [our translation]

The MLP has three levels, all more or less rectilinear in shape, connected by glass-walled elevators and the sculptural 'tree of life' which pierces each level, tying them together. The elevators allow visitors to see the full 16m tall sculpture, Arvore da Vida (Tree of Life), designed by the artist Rafic Farah, with words from different languages that have contributed to the development of the Portuguese language and from contemporary spoken Portuguese in Brazil. Visitors are encouraged to start their visit on the third floor, but they may also start on the ground floor, and work their way up. The entire exhibition space on the ground (first) level is reserved for temporary exhibitions. ${ }^{3}$ Each of these are major reconfigurations and reinterpretations of the space, focusing on particular Brazilian writers or on different themes related to language. When it first opened, the museum's main exhibition was Grande Sertão: Veredas, written by João Guimarães Rosa in 1956, and widely considered to be one of Brazil's greatest works of literature. Other exhibitions have focused on great writers, such as Machado de Assis, Cora Coralina, Fernando Pessoa (from Portugal), Clarice Lispector,

${ }^{3}$ Following Ravelli (2006), we follow a rank-based analysis, with 'museum/institution' as the highest rank, followed by 'exhibition', then 'exhibit'. 
Oswald de Andrade, Ruben Braga and Jorge Amado, as well as on related themes such as "Palavras sem fronteiras - Mídias convergentes" (Words with no Borders - Convergent media); "O francês no Brasil em todos os sentidos"(French in Brazil in all its meanings) and Narrativas Poéticas (Poetic Narratives). Temporary exhibitions may be installed for a few months or up to a year, and are major attractions.

Level 2 is the permanent exhibition space, focusing on the history and development of the Portuguese language, as well as cultural expression and regional variation. Level 3 is the auditorium and Praça da Lingua (Language Square). Visitors first enter a cinema showing a ten-minute film about the Portuguese language, and then enter the Praça da Lingua - a domed, planetarium-like area - to experience an immersive installation. When this finishes, visitors may go to the other floors or return to the queue to watch the film and/or the exhibition in Praça da Lingua again.

Since its opening, the MLP has been phenomenally popular, with nearly 3 million visitors attending in the first six years (CAVENAGHI et al., 2014, p. 131). As Cavenaghi et al. (2014) also note, more than 70\% of the visitors are from the city of São Paulo itself, the majority of whom are women, and are likely to have a university degree. Most importantly, more than $70 \%$ of visitors are repeat visitors, suggesting that the experience is more than worthwhile.

\section{Analysing spatial texts as communicative resources: a so- cial-semiotic approach}

This paper begins with the assumption that spatial texts - buildings are an important communicative resource, and are as replete with meaning as any written, spoken or visual text. Without a doubt, members of any given culture respond to the built texts of their environment in myriad ways, be it positively, negatively or neutrally. Spatial texts are an inherent part of our social world, contributing to how we live, work and play. A spatial text, however, is more than a mere physical building itself and its architecture; it also includes its content within and without, as well as how it is used by people. A spatial text is thus "the synthesis of building, space, content and user” (RAVELLI; MCMURTRIE, 2016, p. x). Spatial texts are inherently multimodal, including the material resources used to construct a building; forms of decoration and furnishing; aspects of design, such as spatial dimensions and layout; the use of light or sound; and so on. 
Spatial texts have long been the study of critical analysis, from perspectives as diverse as cultural studies (GROSZ, 2001; KRACAUER, 1997), philosophy (BENJAMIN, 2009; LÉFÈBVRE, 1991), phenomenology (HEIDEGGER, 1997), sociology (SIMMEL, [1909] 1997), semiotics (ECO, 1972, 1977, 1997; PREZIOSI, 1979), and, of course, from the perspective of architecture itself (e.g. CHING, 2007; FORTY, 2000; HERTZBERGER, 2005; LEACH, 2010, UNWIN, 2009). As multimodal, communicative resources, spatial texts have been analysed by a number of scholars, including Bowcher and Yameng Liang (2014), McMurtrie (2011; 2013), O'Toole (2004, 2011), Ravelli (2000; 2006), Ravelli and McMurtrie (2016), Stenglin (2004; 2009), van Leeuwen (2008) and Ventola (2011), among others. These approaches are characterized by taking a social semiotic approach to communication, exemplified in the work of Michael Halliday on language (HALLIDAY, 1978; HALLIDAY; MATTHIESSEN, 2014) in his famous model of systemic-functional linguistics, adapted and extended to visual texts by Gunther Kress and Theo van Leeuwen, in their seminal Reading Images: the Grammar of Visual Design (2006). While there are complementary approaches to multimodal communication (BATEMAN, 2008; NORRIS, 2004; O'HALLORAN et al., 2011), it is the approach of Kress and van Leeuwen (2006) which underpins the analysis presented here.

In this approach, and deriving from the work of Halliday, meaning is seen to be made up of not one but three, intertwined strands. These include meanings about content: what things are and what they do, or representational meanings (the experiential metafunction in Halliday's model). Another strand is that of interactional meanings, that is, meanings about relations: how interactants in a text are positioned vis-à-vis each other, and what attitudes and evaluations may be incorporated (the interpersonal metafunction). The third is organizationalmeanings, that is, meanings deriving from the way different parts of a text may be related to each other in order to create the whole (the textual metafunction). Any one text is a composite of all three types of meanings, which are always co-present. These meanings both arise in, and simultaneously contribute to, social and cultural contexts. Furthermore, each type of meaning is related to specific resources in the text, that is, analysis must be based on identifiable features in the text, not merely on interpretative commentary.

In a complex, multimodal text, one of the challenges is to define what 'the text' is. In a spatial text, such as a museum, analysis needs to oscillate between the institution as a whole, and its component parts, such as 
exhibitions and exhibits. It also needs to oscillate between the perspectives of 'looking at' the spatial text - as if it is a 2D image - and 'moving through' it, in three dimensions (RAVELLI; McMURTRIE, 2016; cf. McMURTRIE, 2013). As the MLP has three clearly differentiated levels, the main focus of the present article is to analyse the key features of each level, as well as how the three levels work together in the museum as a whole, beginning with the analysis of the three strands of meaning.

The analysis of representational meanings can begin with something as simple as identifying what is denoted - what materials are used, what objects are present and so on - as well as exploring what these might connote - their symbolic or cultural values, intertextual references and so on. The functions and uses of included items (chairs to sit on, games to play with) contribute further to the construal of representational meanings (O’TOOLE, 2011; RAVELLI, 2006). Most importantly, spatial texts need to be analysed in terms of the process types they both manifest (what we can 'see' in them and what they represent) and enable (what users can 'do' with them). Following Kress and van Leeuwen (2006), there is a fundamental distinction between narrative process types, which suggest action through the presence of visible vectors, and conceptual process types, which suggest stasis through the absence of visible vectors (See also RAVELLI; MCMURTRIE, 2016) for further description of process sub-types and their identification in spatial texts).

A number of different tools are needed for the analysis of organizational meanings, all of which are concerned with identifying how the various components of a text are brought together to make a meaningful whole. As described by Kress and van Leeuwen (2006), the placement of components in relation to each other determines their Information Values, for example, elements placed above others have the culturally-laden value of being the 'Ideal' or the promise. Framing identifies whether the components are strongly or weakly differentiated, that is, shown to be separate or shown to be more unified, and Salience accounts for the relative prominence of one element in relation to others. This intersects with the Navigation Path (RAVELLI; McMURTRIE, 2016), which accounts for the relation of components to each other as the text unfolds, or as it is moved through by interactants.

Interactional meanings are analysed with two related sets of tools. The first set concerns how interactants are positioned vis-à-vis each other; the interactants here are both the institution of the museum itself and the visitors who attend. As described in Ravelli and McMurtrie (2016), interactants may be positioned through various devices as more or less equal 
to each other in terms of Power (for example, very high ceilings may make a visitor feel small); as more or less able to make direct Contact with the text (for example, whether visitors can easily see an exhibit); as more or less Involved with the text (for example, whether a room can be entered directly or needs to be approached obliquely); as more or less close in terms of Social Distance (for example, whether visitors can touch objects or see them only from behind glass); and as more or less free in terms of Control (for example, whether visitors can move where they want or need to follow a set path). The second set of tools for analysing interactional meaning concerns how interactants are made to feel within the space: how comfortable and how secure, as well as the extent to which interactants identify with the text and feel affiliated with it. These are called Binding and Bonding, respectively (Stenglin, passim). For example, a close, dark room may make some visitors feel uncomfortable, and one with a lot of national symbols may encourage visitors to identify with the space. In addition, the overall Modality of the text needs to be considered, that is, to what extent it is presented as being 'truthful' or 'real' (for example, exhibits may be actual objects, replicas or fanciful interpretations), as well as the degree of Spatial Engagement (McMURTRIE, 2012), that is, the extent to which the space allows for multiple voices (for example, whether the 'authorial voice' of the institution is strongly present, ruling out other interpretations, or whether the design of the space enables more diverse interpretations).

It is important to differentiate the sense of interactional meanings as used here, with other uses of terms such as 'interactivity', 'engagement' or 'participation' in museum contexts. In museum contexts, 'interactivity' can have a narrow, technical sense, referring to devices 'which invite an explicit response from visitors' (RAVELLI, 2006, p. 70). But museum scholars are likely to define interactivity more broadly, to include not just this spatial sense, but also adaptive interactivity (SCREVEN, 1995), or spatial and dialogic interactivity (WITCOMB, 2003), which enables visitors to negotiate meanings, and not simply receive them 'passively'. For our purposes, interactional meaning refers to any aspect of communication which is concerned with 'the ways in which interlocutors engage with each other in the communication process. Museums, through their communicative practices, take up a 'speaking role', and enable roles to be taken up by others, both visitors and relevant communities' (RAVELLI, 2006, p.70). This includes the style and stance of communication and the affectual responses of visitors (see also McDONALD, 2007). Thus interactional 
meaning includes the explicit, technical sense of interactivity, but it is also much broader, encompassing any communication practice which realizes the voice, style and stance of communication, and the roles that different interlocutors may take on.

Overall, we are trying to capture key features of the museum as a whole - how it works for the visitor and what they experience as they move through it. At the same time, this can only be done by accounting for what goes on at a more micro-level, in terms of specific exhibitions and even details of specific exhibits. The focus is not, however, on a full analysis of each micro-component of each exhibition. Our account is a combination of our own experience of moving through the museum, informal observations of visitors in situ and how they interact with exhibits, and our analysis of the exhibits as multimodal texts, that is, instantiations of systemically-available, meaning-making options. Visitor interviews and additional analyses of visitor movements and behaviours (e.g. following McMURTRIE, 2013) could add further insights.

\subsection{Level One: Temporary Exhibits}

In addition to the temporary exhibitions, the east part of Level One contains the administrative offices and a classroom for 50 people. The opening exhibition, "Grande Sertão: Veredas" (Rebellion in the Backwaters), curated by Bia Lessa, was a particularly dynamic exhibition in terms of opportunities for visitor engagement. Visitors could pull scrolls down from the ceiling and see drafts of the original text; look through peepholes in a large map of the Sertão area to see the backwaters; climb up on ladders to see an exhibit from a special vantage point; use mirrors to look into pools of water to see extracts of the text, which were otherwise written in reverse. To 'see' anything, visitors had to be physically involved, and change their vantage point. Subsequent temporary exhibitions have continued to pursue various strategies for engaging visitors, including one of the most recent, Poesia Agora (Poetry Now), from June 23 to September 27, 2015, with innovative poems selected from 500 talented but non-canonical poets. In this specific exhibition, curated by Lucas Viriator, visitors could listen to, read, watch videos and write different kinds of poems, displayed in different spaces: walls, mirrors, paper and videos. They could also choose to watch different videos related to poetry projected by light in big cylinders (cones): a documentary, theatrical performances, and poems being recited by the poets 
themselves. In another part of the room visitors could also listen to words randomly and read poems displayed on four white panels. In an adjacent room, there were empty books where visitors could write whatever they wanted, or, alternatively, watch videos with poets talking about their work. For this temporary exhibition, people who found poems on the streets, in graffiti, could take pictures and send the images to a specific e-mail address (participepoesiaagora@gmail.com).However, for the purposes of this study, the analysis will focus on the original exhibition, Grande Sertão: Veredas.

In representational terms, the materials used throughout the exhibition were both rustic and industrial: paper, wood, petrol drums (which held the pools of water), and clusters of fallen or abandoned building materials (bricks, sand, water, wood). The colours were earthy, with a predominance of red as a point of contrast. All these are symbolic of the area, and connote the area where the book is set, its characters (e.g., Riobaldo, Diadorim, Zé Bebelo, Joca Ramiro, Ricardão) and its themes (e.g., the devil and murder, symbolized by the red colour). In terms of process types, each exhibit on its own (the map on the wall with peepholes, the scrolls, the petrol drums, etc.) might be analysed as conceptual processes, and more specifically, the subtype of structured analytical (KRESS; van LEEWEN, 2006), with the exhibit as the whole being the Carrier and its component parts being its Attributestypically fragments of the book. Yet each of these otherwise static exhibits only 'comes alive' with the physical engagement of the visitor. That is, with the inclusion of the visitor, the exhibits are more appropriately analysed as narrative processes and the visitor takes on active, agentive roles, such as the Actor climbing the ladder as Range (KRESS; van LEEUWEN, 2006; HALLIDAY; MATTHIESSEN, 2014), pulling down the scrolls, or holding the mirror (See Figure 2). The visitor then becomes the Reactor looking at the exhibit, while the text fragments, the writing, become the Phenomenon. Visitors must act before they can see, and see before they can read or understand. ${ }^{4}$ In turn, when engaging in these processes, visitors themselves then become an integral part of the exhibit - a Phenomenon to be observed by others. There are no highly technological exhibits here (no computers to manipulate, no buttons to activate), but the representational design of the exhibition as a whole places the visitor in the centre of meaning-making processes. Cavenaghi et al. (2014, p. 139) confirm that such interactivity "faz

\footnotetext{
${ }^{4}$ Some of these features can be seen in the video <https://www.youtube.com/ watch?v=ApLLtCZoA8Y $>$ (accessed December 2015).
} 
com o que o visitante seja um agente ativo e não meramente um espectador" ("allows the visitor to become an active agent, not merely a spectator"). Language, in this exhibition, is construed as something intrinsic to the nature of this book, and as something almost ephemeral, which must be viewed in a particular way, before it can be understood.

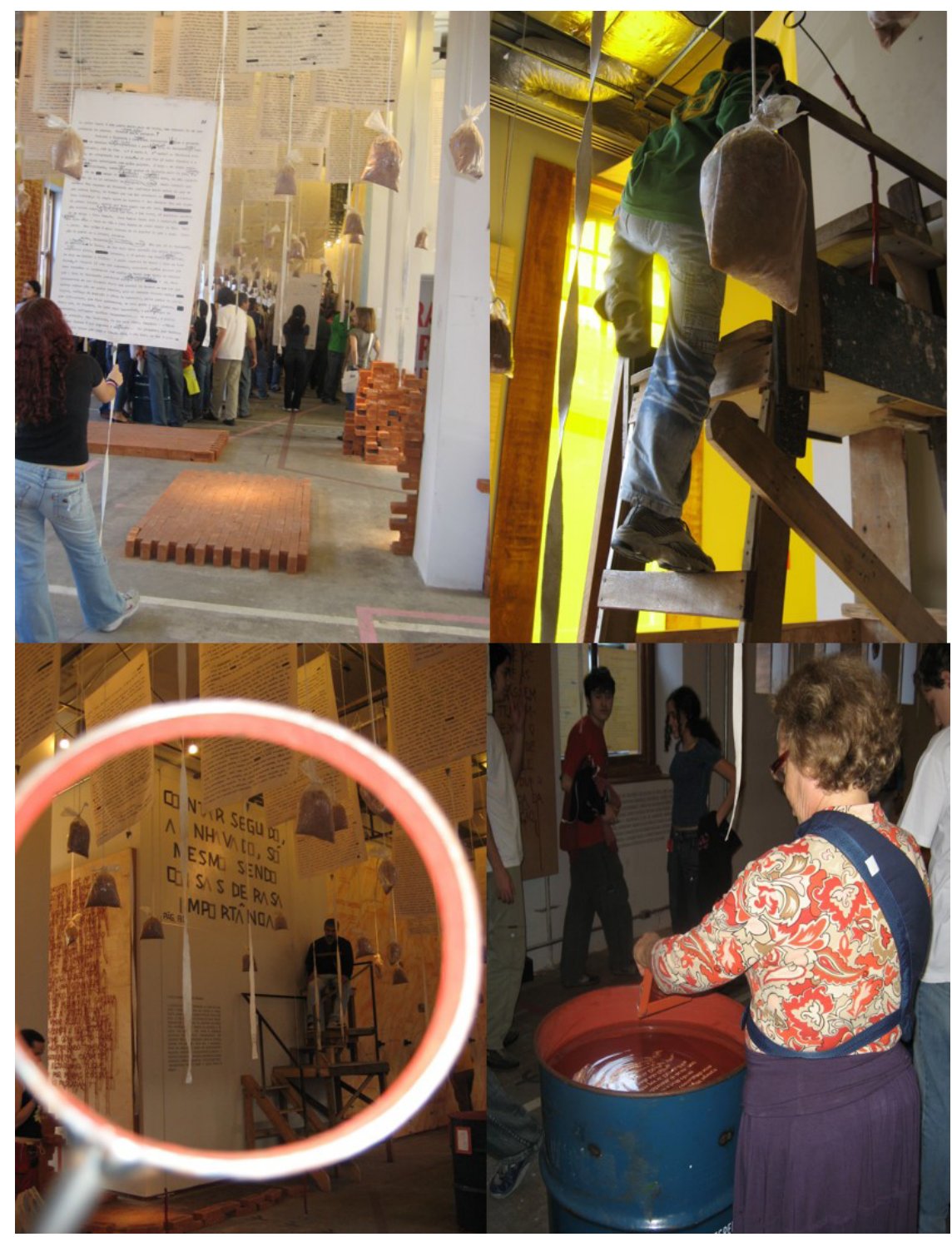

FIGURE 2 - Images from the Grande Sertão: Veredas exhibition (Photos: authors, 2006) 
Organizationally, the exhibition space is largely open. The rectilinear organization of the entire level suggests a general movement from one end to the other, but visitors are largely free to move around the individual exhibits as they wish, and in any order. Thus, on the horizontal plane, there is no clear Information value, there is no evident Centre/Margin structure, nor Triptych, nor Before/After (RAVELLI, 2006). This, too, is symbolic of the region in which the book is set, as it is famous for having many paths (veredas), which criss-cross each other, and these paths are also visually present on the floor. For the exhibition as a whole, there is also no clear point of salience, except perhaps for the map on the wall, which is particularly large and highly symbolic; otherwise, each exhibit would seem to be equal in value, with none more important than any other. Similarly, while the exhibits (that is, the scrolls, the petrol drums, the map, the clusters of building materials) are distinctive and separate from the others, they are also weakly framed, with no distinct borders between them, and with an overlapping of sounds (from other visitors), all contributing to the cohesion of the space, as does the evident consistency of design in terms of colours and materials.

However, for each individual exhibit, specific information values are evident, as are key points of salience. In particular, exhibits play with the construal of Ideal and Real, Ideal values being placed up high, and signifying a 'promise' or 'what might be', and Real values being placed down low, and signifying the concrete, or 'what is' (KRESS; van LEEUWEN, 2006, p. 186). Thus, the scrolls are at first up high, rolled up, but when pulled down by the visitor, the text of the scrolls comes into the space of the Real, where the visitor can read and appreciate it. At other points, the visitor's usual location in the space of the Real, i.e. on the ground, often looking up at exhibits, is reversed when they climb up a ladder, to view the exhibit on the ground. Through such devices, the key Attributes of the exhibit, or the Phenomena which are viewed when the visitors play their part, take on salience, that is, receive additional attention. Importantly, this movement also results in a change of perspective for the visitor, that is, by looking through a point of focus, the mirror, or the peephole. Again, the visitor's physical engagement is not merely a generalized sense of interaction, but it is both realized by and contributes to the re-construal of organizational meanings as well.

For interactional meanings, the design of this exhibition invites direct Contact, an intimate Social Distance, and strong Involvement: visitors can 
see and touch everything, since they have pulled down the scroll, climbed the ladder, peeked through the peephole and so on. Control is relatively weak: visitors can move through the exhibition how and when they want. The open and multiple pathways construe a heteroglossic voice on the part of the institution, that is, the open pathways enable visitors to 'move around and gain alternative perspectives within the space' (RAVELLI; McMURTRIE, 2016, p. 75).

In terms of Binding, the space is strongly unbound, with a very high ceiling, plenty of natural light, and light colours for the ceiling, walls and floor. Some parts of the space are more strongly bound, with exhibits hanging down from the ceiling, closing in that part of the space, but most visitors would likely feel more secure and comfortable with the openness of the exhibition space as a whole (although the sheer number of visitors can make it feel much more enclosed!). The Bonding potential provided by the cultural significance of the book Grande Sertão: Veredas is very strong: this text is studied in school, and it is much loved in Brazil. Segments, phrases and words from the book are well-recognized, and these, along with symbolic representations of the area, the characters and themes of the book, function as strong Bonding icons (STENGLIN, 2004) for this exhibition. At the same time, the exhibition is highly hybridized: there are many things for visitors 'to do' (climb the ladder, pull down the scrolls...), making it a very dynamic and engaging exhibition. In interactional terms, therefore, the space is highly inviting, and one with which Brazilian visitors are likely to identify strongly.

The map itself on the wall (Figure 3) is somewhat realistic; it bears some relation to the 'real' place but functions primarily in terms of a symbolic or generalized representation, that is, it does not have high modality from a naturalistic or scientific coding orientation (KRESS; van LEEUWEN, 2006). From these coding orientations, it has low modality. This is also true of the rest of the exhibition: these are not 'real' scrolls, book extracts or building materials. They are somewhat realistic but function in such a way as to represent key elements of the book. Indeed, one of the text panels alludes exactly to this:

The map and the exhibition play with the notion of real and imagined [fictional] space. The map [on the wall] is a kind of organism - it reflects the multiple, nonlinear temporalities of the book. Sertão [the area] is everywhere. [our translation] 


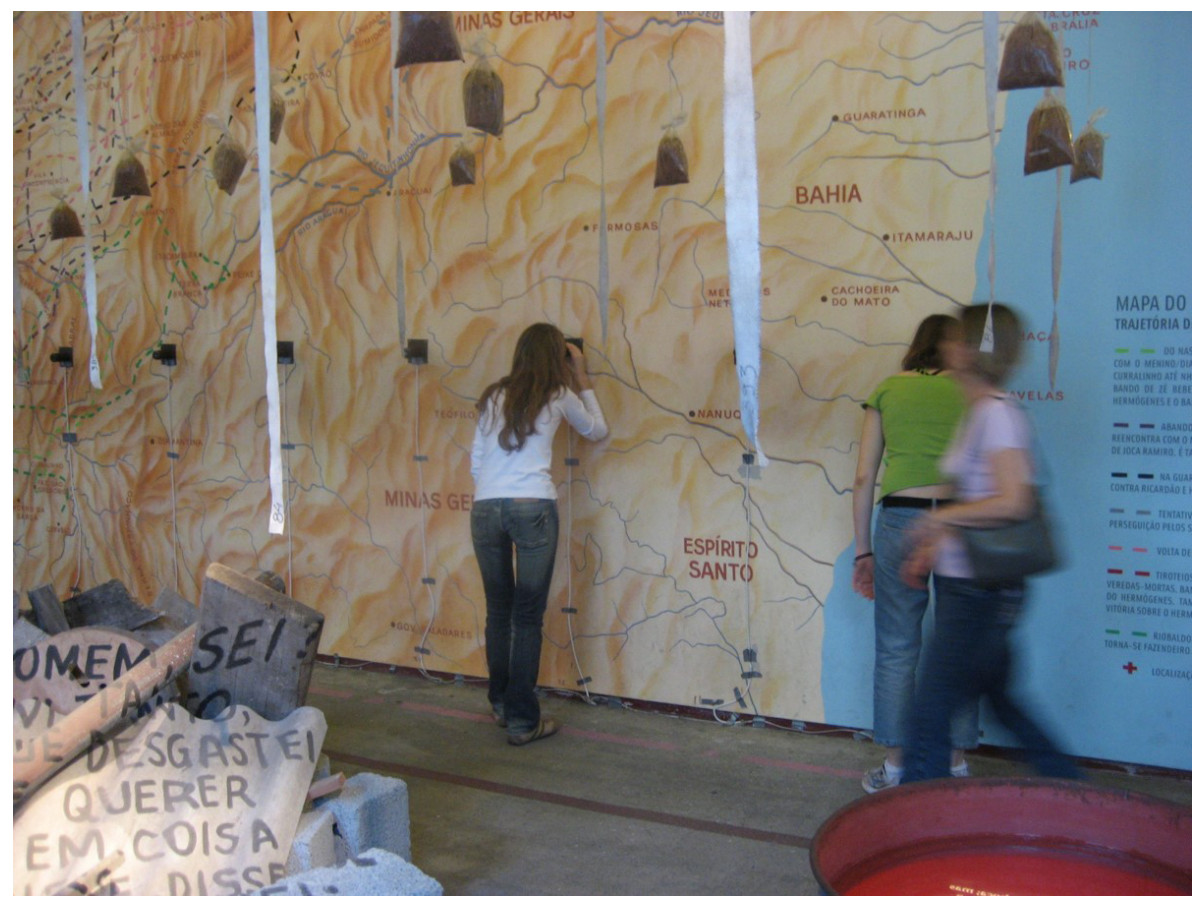

FIGURE 3 - Map in the Exhibition, Grande Sertão: Veredas (Photo, author, 2006).

\subsection{Level Two: Permanent Exhibitions}

On Level 2, visitors find the Grande Galeria (the Great Hall); Palavras Cruqadas (Crosswords); Linha do Tempo (Time Line); Beco das Palavras (Words Alley); História da Estação da Lur. (History of the Luz Train Station) and Mapa dos Falares (Map of the different ways of speaking). In the Grande Galeria (Great Hall)", visitors can walk along a straight path on one side of the space watching a 106 meter-long screen that projects simultaneous films, illustrating the use of the Portuguese language in everyday life and in the history of users of the Portuguese language. As explained on the screen,

In this $106 \mathrm{~m}$ long screen, which occupies the entire extension of the Estação da Lur [Luz train station], we portray the richness and diversity of the Portuguese language. A language in constant movement.

\footnotetext{
${ }^{5}$ For a good overview of this level, see https://www.youtube.com/watch?v=-yNFhmS35jY, by Prof. Tiago Xavier (accessed December 2015).
} 
At each stop, a door opens, showing a slice of what we have as the most original: the language of the everyday life, in songs, soccer, Carnival, cooking, buman relations, festivities, nature, religions and dances. It also emphasizes the Portuguese root that has founded our identity. [our translation]

The simultaneous projections resemble the movement of a train. The films show common Brazilian people, as well as Brazilian movie and TV stars, from different places throughout the country acting in different ways, using expressions and slang from different decades.

Another part of the permanent exhibition, called Palavras Cruzadas, (Crosswords), is made up of large pillars that display information regarding contributions to the development of spoken Brazilian Portuguese, from languages such as French and English, as well as from indigenous peoples and immigrants. Another pillar is also related to other Portuguese-speaking countries in the world.

Near the pillars, occupying the entire wall opposite the Great Hall, visitors can also find information about the history of the Portuguese language and choose to use several interactive resources, such as videos, music, pictures, diagrams, maps and audio recordings (Linha do TempoTime Line). In this Time Line, visitors find that contemporary Brazilian Portuguese derives mainly from three different sources: 1) influence from Europe (from 4000 BC on, Indo-European); 2) native indigenous languages from the Brazilian territory, especially from the Tupi peoples; and 3) African cultures, in particular those of Congo and Nigeria. According to the information on the signs in the MLP, from the XVI century on, these three sources meet to form the time line of what is known as the Brazilian Portuguese language.

Visitors can also enjoy surveying a map of Brazil regarding the different variants of spoken Portuguese (Mapa dos Falares - Map of the different ways of speaking). By choosing a specific place on the map, they may then listen to people from that particular place and pay attention to accents and lexicogrammatical curiosities. They can also see the first official document written in Portuguese in 1000, or observe the influence of the Semana de Arte Moderna (Week of Modern Art), in 1922, on Brazilian culture. At the end of this time line there is a mirror and a note telling visitors that the person being portrayed in this mirror is the representation of present-day language, suggesting that each speaker refines the language even further (See Figure 4). 


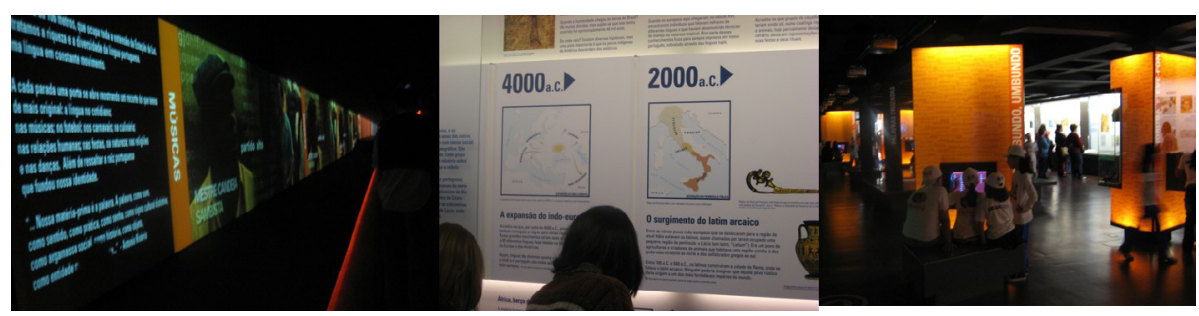

FIGURE 4 - Various aspects of Level 2 (photo, author, 2006).

An adjacent room (Beco das Palavras - Word Alley) contains an etymologic interactive game for visitors to play with words, their origins and meanings. Still on Level 2, in the section called História da Estação da Luz (History of the Luz Train Station), there are posters displaying information about the building where the museum stands as well as historical facts about the famous train station (Estação da Luə), adjacent to the museum.

The overall design of Level 2 is distinct from Level 1 (and, as we will see in Level 3) in terms of each of the metafunctions. Representationally, the exhibits here are more literal, rather than symbolic, as on Level 1. The Portuguese language is represented in a number of different ways: the maps and pillars construe conventional etymologic origins, showing superordinates and subordinates, with the connecting lines between languages suggesting processes of transformation (KRESS; van LEEUWEN, 2006). Thus, language is, at least in part, a sum of where it comes from. But language is also construed as part of everyday experience, and as something living: language is spoken, remembered and passed on by people, as portrayed in the videos and audio recordings. Language is further construed as fun, as witnessed by the etymologic game: here, visitors stand around rectangular tables, the surface of which are screens where word parts zoom in and out of the screen; visitors need to 'capture' these (moving them with their hands) and put them together appropriately, to make actual words. Thus language is something which can be played with.

Level 2 is also distinctive in organizational terms. Visitors are likely to be attracted to the movement and sound of the film screen first; this could therefore be seen as 'Given' in relation to the 'New' of the pillars and time line. That is, the cultural experience is established first, and presented as understood, whereas the more technical information of origins and history is presented as fresh. Alternatively, the central placement of the pillars within the space as a whole could be said to mediate both the film 
and the time line in a triptych fashion, that is, making the historical origins of the language central to the understanding of both culture (in the film) and technical details (in the time line). If visitors do go to the film first, the projections there merge and overlap with each other, suggesting that this is one continuous experience, but the directionality of the screen also construes a Given/Before vs New/After value - the classic museum effect of 'transforming' the visitor (RAVELLI, 2006). Most of the other exhibits are presented to the right hand side, and while there is no necessary order for the exhibition as a whole, conventional movement patterns suggest a general directionality. Interestingly, the etymologic game is positioned at the end of the space, behind a wall. In terms of information values then, this has a clear New/After information value; that is, the 'fun' comes after the more serious business! Also, many of the individual exhibits, especially the more conventional text panels, have a typical Ideal/Real construction, with headings and generalized information at the top, and more specific information towards the bottom. Within this level, the projections are highly salient because of their dynamism and auditory impact; the various spaces within this level are unified by weak framing, such as consistent background colouring, but they are also separated by empty space and changes in design, to differentiate areas such as the time line and the pillars, and with a wall marking strong separation from the etymologic game.

Perhaps the most dramatic shift between the first and second levels is in interpersonal terms. While the exhibition is still engaging and dynamic, there are fewer opportunities for visitors to physically manipulate the exhibits (though there are still some), and a number of exhibits are encased behind glass, or are fixed to the wall and can only be viewed in that way. Thus, Contact and Involvement are somewhat less, and Social Distance a little greater, than on Level One (everything can still be seen, but sometimes behind glass; it cannot all be touched). With less open pathways, the sense of Control is slightly greater, and there is less heteroglossia, though visitors still have some opportunities to determine the finer details of their pathway. The modality of this level is higher in terms of a naturalistic coding orientation: many of the presentation techniques (pillars, text panels, etc.) are familiar from conventional museum practice. There is, therefore, a strong sense of this being a 'real' museum. Further, the ceiling here is much lower than on Level 1, and the lighting and background colours are much darker. Thus, the space is more strongly bound. This strong contrast in terms of Binding 
is a great way to refresh the visitor's experience of the museum as a whole (STENGLIN, 2004). The potential for bonding is still strong: images of both everyday and well-known people are an opportunity for identification, as are the etymological origins of Portuguese, as visitors learn more about their native language. With reduced visitor roles, however, there is a lower level of hybridization, and even with the film projections and etymological game, this level feels mostly like a 'conventional' museum.

\subsection{Level 3: Auditorium and Praça da Língua}

On the third level, there is an auditorium where visitors watch a 10-minute film about the origins of the Portuguese language (Our language is our DNA), with a voice over by a famous Oscar-nominated Brazilian actress, Fernanda Montenegro. After the film, participants are invited to go to an amphitheater called Praça da Lingua (Language Square), which projects images with words, poems and excerpts of text from different Brazilian or Portuguese authors, onto a domed ceiling, somewhat like a planetarium. Visitors sit around the edge, facing the centre, and the experience is highly immersive. The projections are part of an anthology of literature, with José Miguel Wisnik and Arthur Nestrovski as curators, and move dynamically all over the ceiling, with a strongly reverberating sound track of words and music. For the purposes of this paper, we will analyse only the Praça da Lingua.

In the Praça da Lingua there is a constant projection, visually and aurally, of fragments of culturally-significant texts (songs, poems, sayings, novels, etc.). While all of these move continuously - across the domed ceiling, in and out of the audio track - the movement here is more about salience (an organizational feature). It does not construe active processes between elements (for example, it is not the case that the projection of one set of words pushes or bumps another set out of the space; they merge and blur into each other; appear and disappear). Thus, the projections are more appropriately analysed as conceptual processes. A possible analysis of the subtype of the conceptual process could be as an unstructured analytical process, that is, one where the Attributes (the visual and aural language components) are present, without an identifiable Carrier. The Carrier could be inferred to be what the fragments of text collectively represent: something bigger than the individual parts, not quite superordinate in a taxonomic structure (because there is no symmetry to realize this relationship), 
but something that visitors must infer for themselves (see KRESS; van LEEUWEN, 2006; RAVELLI; McMURTRIE, 2016, for further details on the realizations of conceptual process subtypes). An alternative possible analysis could be a Symbolic Attributive process, that is, one in which the Attributes have symbolic value, by being out of place, holding specific cultural values, or highlighted in some way (again, see KRESS; van LEEUWEN here). Certainly the symbolism of the projections and the sounds are evident: both are presented in an unusual way (on the ceiling/sky or on the walls), they hold inherent cultural values, and they are highlighted by movement and volume. Again, however, the Carrier can only be inferred. This points to a third, and probable analysis, of Symbolic Suggestive. As Kress and van Leeuwen note in relation to visual images (2006, p. 106):

Symbolic Suggestive Processes have only one participant, the Carrier. They cannot be interpreted as analytical, because in this kind of image detail tends to be de-emphasized in favour of what could be called 'mood' or 'atmosphere'. (...) It is this which lends Symbolic Suggestive pictures their genericity, their quality of depicting not a specific moment but a generalized essence ... Symbolic Suggestive processes represent meaning and identity as coming from within, as deriving from qualities of the Carrier themselves...

Thus the most probable analysis is that the Carrier in the Praça da Lingua is language itself: not represented separately from the visual and aural projections, but realized by those projections, with the meaning and identity of language as coming 'from within' the projections themselves. Importantly, as noted by Ravelli and McMurtrie (2016, p.90), such Symbolic Suggestive processes function as Bonding Icons, that is, creating a means of affiliation for those observing them, which helps to explain the emotional impact of the experience.

It is relevant to note that, at the same time, the darkness of the space itself and the positioning of visitors seated around the edge construe these as Circumstances of location (a kind of 'nowhere') and accompaniment respectively; that is, visitors are placed as accompaniments to the unfolding processes. They are immersed in this experience, and themselves can take up the roles of Sensors - looking, hearing - in relation to what they observe and hear (See Figure 5). 


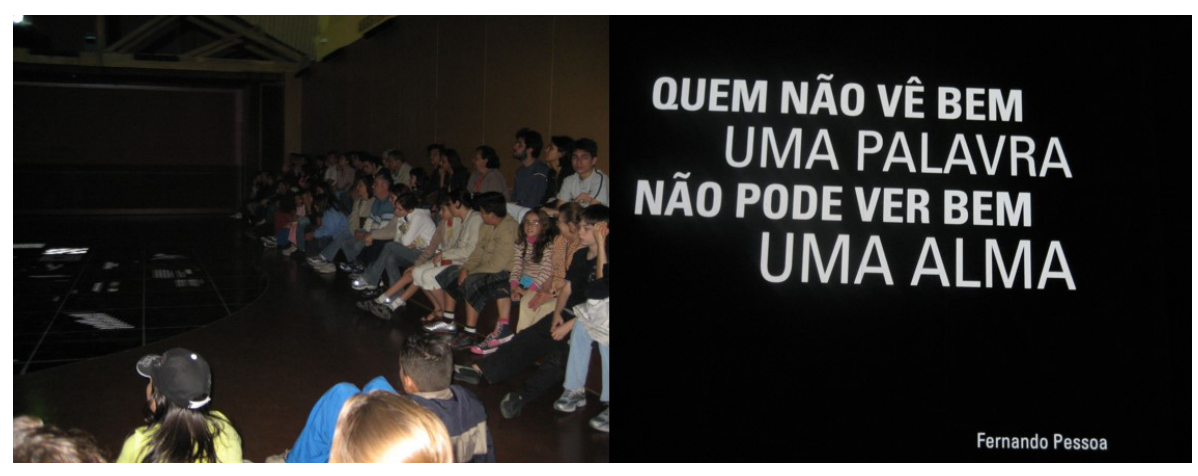

FIGURE 5 - Level 3 Praça da Lingua (Photo, author 2006)

The visitor's role is also significant in organizational terms. While visitors sit around the edge, facing inwards, the height and darkness of the space effectively blur any physical boundaries, and with the domed ceiling suggesting the infiniteness of the sky, there is a strong sense in which visitors are positioned as the Centre of this unfolding process, the nucleus, with the texts (words, images, sounds) as the Margins/Satellites. That is, everything projected within the planetarium is related to the visitor as its nucleus. The experience is, therefore, as much about the visitor as about what is projected. This reinforces the Bonding potential of the Symbolic Suggestive process.

As the whole experience unfolds, there is a complementary synchrony of the projection of words with the sounds being transmitted; they are unified as one text. Different parts may take on momentary salience: because the visual components move, or are enlarged, or speed up; or because the soundtrack increases in volume, or changes in style. But nothing has a consistent priority - as noted above, elements blur in and out of focus, are bigger then smaller, louder and softer, and vice-versa. Framing between components is weak: the consistent black background, the merging of different components of the sound track into one another, all mean that the different elements are presented as one continuous text. Thus, all these elements, whether they are high literature or the voices of children in everyday life, whether a classical or popular piece of music, are presented as equally important. Again this reinforces the representational analysis as Symbolic Suggestive - differences between the components are blurred, rather than distinct.

As with the change between the first and second levels, the change in interactional choices on Level 3 is dramatic. Choices in Contact, Social 
Distance, Involvement and Power are contradictory. On the one hand, visitors can see what is going on (has Contact), but they are positioned at a large physical distance from the very high ceiling, with oblique Involvement and little Power. On the other hand, the immersive nature of the experience, with the sense that language is 'all around', positions the visitor in such a way as to have equal Power, direct Involvement, and minimal Social Distance. This also contributes to a lower modality value in terms of a naturalistic coding orientation, enhancing the wondrous and dream-like effect of the experience as a whole.

Binding is completely different from Levels 1 and 2, and is strongly bound to the deep black space and illumination coming only from the projections. However, with the great height of the dome and the emptiness of the physical centre (visitors sit around the edge and there are only projections on the floor in the middle or on the walls), it is not claustrophobic. The strong Binding contributes to the immersive nature of the experience, and the contrast with Levels 1 and 2 again refreshes the visitor's museum experience. Hybridisation is minimal, but the potential for Bonding continues to be very strong, with the positioning of the visitor as Central to the overall experience, with culturally recognizable written and aural texts, and with the Symbolic Suggestive nature of the process, all reinforcing the emotional impact of the entire experience.

\section{Concluding remarks: the MLP as an interactive, multisemiotic complex}

The success of the museum in terms of engagement and public appeal cannot be disputed, in terms of both visitor numbers, return visits and research on visitor responses. Cavenaghi et al. (2014), for example, undertook in-depth interviews with 17 visitors. Their study focused particularly on the role of technology in enabling interaction, and the visitors' responses point to the integral role of this in the museum's success, for example:

"Não imagino um museu falando de língua portuguesa que não use recursos tecnológicos, principalmente para explorar a sonoridade da língua, os sotaques, e contextualizá-la no tempo e no espaço.” (I can't imagine a museum about the Portuguese Language that does not use technological resources, especially to explore the sonority of the language, the accents, and contextualize it in time and space.). (Interviewee 2, CAVENAGHI et al, 2014, p. 138; our translation) 
According to Cavenaghi et al. (2014, p. 138), contrary to the traditional belief that museums display old materials, the MLP exemplifies the notion that artistic and cultural artefacts can be interactive and attract visitors to participate more directly, as pointed out by one of the interviewees:

"A expectativa era de conhecer, mas havia o receio de ser chato, mas ao visitar isso foi superado, pois é muito interessante e interativo." (The expectation was to get to know the museum, but I was afraid it would be boring, but when I visited it, this was overcome, for it is interesting and interactive." (Interviewee 7; our translation)

Cavenaghi et al. (2014, p. 139) explain that while the interactive affordances in the museum are integrated with the use of technological resources, the technological aspects of the MLP are not only an asset but "uma oportunidade para as pessoas terem acesso a seu acervo de modo imaterial, o que lhes permite participar da exposição de forma ativa, tornando-as também parte da obra." "“an opportunity for people to have access to its immaterial collection/acquis, which allows them to participate actively in the exhibition and become part of the work.”).

We concur with this viewpoint but would add that it is not simply the presence of technology which creates this appeal. Rather, it is the multisemiotic design of the museum as a whole and the way different aspects of meaning - representational, organizational and interactional - are both differentiated throughout the museum, as well as brought together to create an experience which is satisfying, without being exhausting.

Representationally, each level highlights different aspects of what language is and what it means. For the opening exhibition, language was something to engage with, a window to a particular world; on Level 2, language is something which has history and cultural resonance and which belongs to all. On Level 3, it is something which inspires emotion, in relation to which the visitor is central. The changes in representational focus on each level effectively 'refresh' the visitors' experience as they move through the museum; each level has its own identity and purpose, while being connected to the overall themes of language, identity and culture.

In terms of potential definitions and technical explanations of language, the knowledge that is represented is not overwhelming, and is manageable in terms of the visitor's capacity to take in the information, particularly as technical details are largely confined to Level 2 , and even 
there are presented in an engaging way. If the audience for the museum was made up of those who were already linguists, then there could be both further depth in terms of technical details and further breadth in terms of different aspects of language (such as genres, register, critical discourse). But obviously, linguists are not the target audience.

Organizationally, the simple, rectilinear layout of the whole building makes it easy to conceptualize the whole space and move through it. Weak framing unifies the three levels: the parallel floor structure and the tree of life, which breaches each level, show that each level is part of the same space. This operates simultaneously with strong framing devices - the distinct identity and purpose of each level create a separation between each level, which again refreshes the experience for the visitor. In terms of the visitors themselves, they are often placed as the nucleus of meaning in the museum, for example, within the Praça da Lingua. Thus, while the museum is ostensibly 'about' language, it is also 'about' the visitor and their relationship with language.

Interactionally, the museum experience is refreshed at each level by strong changes in binding values. The strong prominence of bonding icons creates many opportunities for visitors to identify with the museum's content and the tendency to open, heteroglossic pathways confirms the visitor's autonomy.

Most importantly, the construal of the visitor as central to the experience through each of the metafunctions makes visitors part of the museum: without them, exhibits do not come to life; language has no purpose or meaning. Representationally, visitors must be active participants; organizationally, they are positioned as being central to the experience; interactionally, they are given opportunities to bond and make their own choices. This is the complex sense in which 'interactivity' is realized throughout this museum as a whole, through all of the metafunctions. The experience is rich without being overwhelming; the opportunities to engage are many; and visitors themselves are intrinsic to the experience. No wonder the queues to enter this museum go out the front door and around the block - and may they soon be back again. 


\section{Acknowledgement}

This article is part of the Project PP/CNPq 313144/2014-1, entitled 'Social practices in contemporaneity: multiliteracies, identities and multimodal narratives' (Práticas sociais na contemporaneidade: multiletramentos, identidades e narrativas multimodais), sponsored by the Brazilian Science and Technology Research Council (CNPq), with a research grant for the second author.

\section{References}

BATEMAN, J. Multimodality and genre: a foundation for the systematic analysis of multimodal documents. New York: Palgrave MacMillan, 2008.

BENJAMIN, A. The urban body. Keynote presentation at Seam2009 Spatial Phrases. University of Technology, Sydney, in association with the University of Hertfordshire, UK, 2009.

BOWCHER, W.; YAMENG LIANG, J. Representing Chairman Mao: a socialsemiotic analysis of two statues on a Red Tour. Visual Communication, Los Angeles et al., v. 13, n. 1, p. 3-30., 2014.

CAVENAGHI, A. J.; NASCIMENTO, A. M.; PEREIRA, V. B. Museu da Língua Portuguesa: tecnologia como atratividade turística na cidade de São Paulo. Revista Confluências Culturais, Joinville, v. 3, n. 1, p. 129-143, 2014.

CHING, F. Architecture: Form, Space and Order. New Jersey: John Wiley and Sons, Inc, 2007.

DIAS, R. WebQuests: tecnologias, multiletramentos e a formação do professor de inglês para a era do ciberespaço. Rev. Bras. Linguist. Apl., Belo Horizonte, v.12, n.4, p. 861-882, 2012.

ECO, U. A Theory of Semiotics. London: Macmillan, 1977.

ECO, U. A componential analysis of the architectural sign. Semiotica, Berlin/Boston, v. 5, n. 2, p. 92-117, 1972.

ECO. U. Function and sign: semiotics of architecture. In: LEACH, N. (Ed.). Rethinking Architecture: A Reader in Cultural Theory. Abingdon: Routledge, 1997. p. 182-202.

FORTY, A. Words and Buildings: A Vocabulary of Modern Architecture. New York: Thames and Hudson Inc., 2000.

GROSZ, E. Architecture from the Outside; Essays on Virtual and Real Space. London: The MIT Press, 2001.

HALLIDAY, M. Language as Social Semiotic. London: Arnold, 1978. 
HALLIDAY, M.; MATTHIESSEN, C. Halliday's introduction to functional grammar. 4. ed. London and New York: Routledge, 2014.

HEBERLE, V. M. Multimodalidade e multiletramento: pelo estudo da linguagem como prática social multissemiótica. In: SILVA, K; DANIEL, F; MARQUES, S. (Ed.). A formação de professores de línguas: novos olhares. Campinas: Pontes, 2012. v. 2, p. 83-106.

HEIDEGGER, M. Art and space. In: LEACH, N. (Ed.). Rethinking Architecture: A Reader in Cultural Theory. New York: Routledge, 1997. p. 121-125.

HERTZBERGER, H. Lessons for Students in Architecture. $5^{\text {th }}$ ed. Rotterdam: 010 Publishers, 2005.

KRACAUER, S. ‘The hotel lobby’. In: LEACH, N. (Ed.). Rethinking Architecture: A Reader in Cultural Theory. London: Routledge, 1997. p. 51-57.

KRESS, G.; van LEEUWEN, T. Reading Images: The grammar of visual design. London: Routledge, 2006.

LEACH, A. What is Architectural History? Cambridge: Polity Press, 2010.

LÉFÈBVRE, H. The Production of Space. Oxford: Blackwell Publishers, 1991.

MCDONALD, S. Interconnecting: museum visiting and exhibition design. CoDesign, Abingdon, v. 3, s. 1, p. 149-162, 2007.

McMURTRIE, R. The genre of foyers in the contemporary high-rise: a study of Harry Seidler's work. Linguistics and the Human Sciences, Sheffield, v. 5, n. 1, p.59-92, 2011.

McMURTRIE, R. Feeling space dynamically: variable interpersonal meanings in highrise apartment complexes. Visual Communication, Los Angeles et al., v. 11, n. 4, p. 1-24, 2012.

McMURTRIE, R. Spatiogrammatics: a social semiotic perspective on moving bodies transforming the meaning potential of space. 2013. 599f. Thesis (Ph.D.) - School of the Arts and Media, Faculty of Arts and Social Sciences, University of New South Wales, Sydney, 2013.

MOTTA-ROTH, D.; HEBERLE, V. M. A short cartography of genre studies in Brazil. Journal of English for Academic Purposes, v. 19, p. 22-31, 2015. Available at: <http://dx.doi.org/10.1016/j.jeap.2015.05.006>.

NASCIMENTO, R. G.; BEZERRA, F. A. S.; HEBERLE, V. M. Multiletramentos: iniciação à análise de imagens. Linguagem \& Ensino (UCPel.), Pelotas, v. 14, p. 529552, 2011.

NORRIS, S. Analyzing multimodal interaction: A methodological framework. New York: Routledge, 2004. 
O'TOOLE, M. The Language of Displayed Art. $2^{\text {nd }}$ ed. London: Leicester University Press, 2011.

O'HALLORAN, K. L.; TAN, S.; SMITH, B. A.; PODLASOV, A. Multimodal analysis within an interactive software environment: critical discourse perspectives. Critical Discourse Studies, Abingdon,v. 8, n. 2, p. 109-125, 2011.

PREZIOSI, D. Architecture, Language and Meaning. The Hague: Mouton Publishers, 1979.

RAVELLI, L.; McMURTRIE, R. Multimodality in the Built Environment: Spatial Discourse Analysis. London and New York: Routledge, 2016.

RAVELLI, L. Beyond shopping: constructing the Sydney Olympics in threedimensional text. Text, Berlin/Boston, v. 20, n. 4, p. 489-515, 2000.

RAVELLI, L. Museum Texts: Communication Frameworks. London; New York: Routledge, 2006.

SCREVEN, G. Motivating visitors to read labels. In: BLAIS, A. (Ed.). Text in the exbibition medium. La Société des Musées Québécois; Musée de la Civilisation: 1995. p. 97-134.

SIMMEL, G. Bridge and door. In: LEACH, N. (Ed.). Rethinking Architecture. New York: Routledge, [1909] 1997. p. 66-69.

STENGLIN, M. Packaging curiosities: towards a grammar of three-dimensional space. 2004. 513f. Thesis (Ph.D.) - Department of Linguistics, University of Sydney, Sydney, 2004.

STENGLIN, M. Space odyssey: a guided tour through the semiosis of threedimensional space. Visual Communication, Los Angeles et al., v. 8, n. 1, p. 35-64, 2009. UNWIN, S. Analysing Architecture. London: Routledge, 2009.

van LEEUWEN, T. Discourse and Practice: New Tools for Critical Discourse Analysis. Oxford: Oxford University Press, 2008.

VENTOLA, E. Semiotisation processes of space: from drawing our homes to styling them. In: O'HALLORAN, K.; SMITH, B. (Ed.). Multimodal Studies: Exploring Issues and Domains. Abingdon: Routledge, 2011. p. 220-238.

WITCOMB, A. Re-Imagining the museum: Beyond the mausoleum. London; New York: Routledge, 2003.

ZACCHI, V.J. Imagem e movimento: o modo visual na construção da identidade do sem-terra. Rev. Bras. Linguist. Apl., Belo Horizonte, v. 9, n. 2, p. 415-439, 2009.

Data de submissão: 06/01/2016. Data de aprovação: 11/04/2016. 